\title{
The PHS Case and Federalism-Based Alternatives to Charter Activism
}

\section{Dwight Newman}

\section{Introduction}

In the recent case of Canada (AG) v PHS Community Services (PHS, often called the Insite Decision), ${ }^{1}$ the Supreme Court of Canada purported to offer a case-specific decision limited to Vancouver's Insite injection facility. The decision saw the Court declare that the Federal Minister of Health could not decline to continue an exemption from narcotics provisions for the Insite Clinic, which provided an injection site for narcotics users in Downtown Eastside Vancouver. Despite the Court's claim to want a case-specific decision, I argue in the present discussion that by basing their decision on section 7 of the Charter, rather than using the alternative federalism argument that was available, the Court adopted a more activist route with more disruptive future legal consequences.

Some academic commentators on the case prior to the Court's decision had commented favourably on possible federalism arguments for the Insite clinic. However, their arguments tended to argue for using the case as one in which to reshape federalism doctrine in the service of particular substantive or political values. ${ }^{2}$ In this paper, I argue that a traditional federalism argument based on a legally consistent application of interjurisdictional immunity ${ }^{3}$ had more potential than the Court acknowledged and that had the Court adopted that federalism argument, it could have avoided a much more problematic section 7 analysis.
To make this argument, first, I will argue briefly that the section 7 reasoning in the case is problematic vis-à-vis the Court's own aim of rendering a case-specific or site-specific result $^{4}$ and instead sets the Court onto a course of more intense judicial activism than has been widely recognized. Second, I will argue that the Court's decision not to engage fully in the federalism analysis involved in the case, particularly on issues related to the doctrine of interjurisdictional immunity, leaves its federalism reasoning laden with logical tensions. The interjurisdictional immunity argument, unlike the section 7 argument, could actually have yielded a relatively unproblematic case-specific argument that would have minimized the reach of the PHS ruling in the way the Court claims to have preferred while also attaining a more democratically legitimate result.

\section{The Activist Results of the Court's Use of the Charter}

My first claim, then, is that the section 7 reasoning in PHS is more problematic than widely assumed and that it marks a return, at least in this instance, of intense judicial activism. Although I will not engage in a full exegesis of the section 7 dimension of the case, since my focus is actually on the federalism dimensions, it is important to say enough about it to support the claim at hand. In its decision, the Court did not use section 7 to analyze provisions of the Con- 
trolled Drugs and Substances Act ${ }^{5}$ itself. Rather, it held that a section 7 violation arose from the Minister's refusal to use provisions of that Act to grant an ongoing exemption from the Act for the Insite facility's injection site. ${ }^{6}$ The conclusion offered by the Court was that, with section 7 interests clearly engaged because of potential prison terms and risks to health, the Minister's refusal to grant the ongoing exemption was both arbitrary and grossly disproportionate and therefore violated the principles of fundamental justice so as to establish a section 7 violation. ${ }^{7}$ These conclusions rested on the findings of the trial judge that the facility did not contribute to increased crime rates in Downtown Eastside Vancouver. ${ }^{8}$ With such a fact presumed at the appeal, the Court considered it straightforward to conclude that the refusal of the exemption did not rationally advance the aim of reduced crime or improved public safety (and was thus arbitrary) and that the costs imposed on individuals whom the facility might help by shutting down the facility were grossly disproportionate to the (non-existent) gain. ${ }^{9}$

In this reasoning, the courts inserted a newly intensified scrutiny for government decisions based on the courts' own reading of appropriate balances between values like public health and public safety. ${ }^{10}$ The Supreme Court made itself the ultimate arbiter of such points as whether " $t]$ he effect of denying the services of Insite to the population it serves is grossly disproportionate to any benefit that Canada might derive from presenting a uniform stance on the possession of narcotics." 11 The trial judge's finding that the facility did not impact on crime in Downtown Eastside Vancouver does not actually speak to the significance of a "uniform stance." The Supreme Court of Canada's conclusion in that regard followed only seven lines of reasoning, showing that the Court considered it unnecessary to engage with the significance of a uniform stance. In the United States Supreme Court, there have been a set of rich arguments concerning the significance of uniform application of narcotics restrictions even in the context of significant rights claims on the other side of the ledger. ${ }^{12} \mathrm{~A}$ uniform stance may be of value because it emphasizes the seriousness with which the government regards narcotics issues and avoids legalizing narcotics in some context from which there can be trafficking to others. These arguments could be mistaken, but they cannot reasonably be quickly ignored. The Supreme Court engaged in next to no analysis of the broader values at stake and simply deferred to factual findings in a way that sets it up as prey to trial-level factual findings in future cases.

This prioritization of quick social science reasoning over a more humanistic understanding of life that leaves room for a range of values not easily measured by social science actually cannot remain case-specific or site-specific. Unsurprisingly, in addition to a surge of discussion about safe injection sites elsewhere, the case has served as a precedent in other contexts engaging section 7. Because $P H S$ permits intense scrutiny of government policies for their effects on particular individuals without leaving room for a weighing of larger values, it establishes an intense form of scrutiny. That intense scrutiny now mandated in section 7 cases has already helped motivate the British Columbia Supreme Court to strike down criminal law provisions against assisted suicide ${ }^{13}$ and the Ontario Court of Appeal to uphold a trial judgment striking down various prostitution-related provisions. ${ }^{14}$ More will no doubt follow.

The very people who pushed for the result in PHS might yet get an unexpected result that they presumably do not want. Specifically, if the logical results are pursued on health care more broadly, one should note the statement in the PHS decision that " $[\mathrm{w}]$ here a law creates a risk to health by preventing access to health care, a deprivation of the right to security of the person is made out [...]." ${ }^{15}$ To reach the PHS result, the Court has interpreted past authorities into the proposition that any risk to health arising from barriers to health care access is now a section 7 deprivation. This proposition has major implications for litigation related to the public health care monopoly. Thus, there are very significant implications flowing from the PHS decision for a range of issues.

It is frankly farcical to think of $P H S$ as a sitespecific or case-specific decision. The Court's approach to section 7 has massive implications for a range of major public policy issues, rang- 
ing from euthanasia to prostitution to the public health care monopoly. In its approach to section 7 , the decision is actually highly activist.

\section{Tensions within the Court's Federalism Discussion}

The brief federalism portion of the PHS decision considers several different arguments, with interjurisdictional immunity being the main one. However, before reaching interjurisdictional immunity, the Court rejects an argument by the intervener Attorney General of Quebec that federal legislation becomes ultra vires within the specific context at issue. ${ }^{16}$ Second, it rejects a claim to the limited application of federal criminal statutes when they conflict with provincial statutes furthering the public interest. ${ }^{17}$

Despite being a significant argument in the case and one that had been adopted at the Court of Appeal level, McLachlin CJC rejects interjurisdictional immunity over the course of a few short paragraphs. ${ }^{18}$ In general terms, the doctrine of interjurisdictional immunity essentially says that one level of government's legislation is inapplicable to the extent that it would intrude on the core of another level's head of power, particularly in relation to a work, thing, or undertaking under that head of power. ${ }^{19}$ It is thus a doctrine geared to reflecting the exclusivity of powers, which is a well-established feature of Canadian federalism flowing from the wording of the Constitution Act, $1867^{20}$ and general federalist principles.

Instead of recognizing it on the facts of the case, McLachlin CJC takes the opportunity to express reasons for caution about interjurisdictional immunity generally, referring to its possible tensions with trends to concurrency and with so-called cooperative federalism ${ }^{21}$ and to the danger that it allegedly generates "legal vacuums." 22

On matters more specific to the case, the judgment cites three reasons for not recognizing interjurisdictional immunity in this instance: that the core of a provincial power over health has not yet been identified in the jurisprudence; that the claimants had not delineated a specific "core" to this power; and that there was a risk of creating the so-called "legal vacuums." 3

The idea of interjurisdictional immunity operating in favour of the provinces (or, what I alternatively call "provincial interjurisdictional immunity") does not differ from the main doctrine. It is also not a new idea, though the Supreme Court of Canada had not fully recognized it until its 2007 decision in Canadian Western Bank. ${ }^{24}$ There, the Court deliberately affirmed the reciprocity of interjurisdictional immunity (federal and provincial) at multiple points in the judgment. ${ }^{25}$

The Court's failure to apply provincial interjurisdictional immunity in PHS, however, will have given analysts some pause. If provincial interjurisdictional immunity will not protect the core of provincial health care jurisdiction, ${ }^{26}$ they might wonder, then what will it protect? My argument is that, given the logical tensions in the Court's discussion of interjurisdictional immunity in PHS, it seems that the Court simply tried to avoid using the doctrine rather than actually limiting it. But the claim of logical tensions in the Court's approach necessitates a bit of unpacking.

In the past, application of interjurisdictional immunity to protect the core of federal areas of jurisdiction never gave rise to any particular tension with the doctrine of federal paramountcy. Indeed, interjurisdictional immunity protected federal heads of power against the provinces, and so did federal paramountcy, therefore both worked as doctrines favouring centralization of power. The relatively recent judicial recognition of the reciprocal role of interjurisdictional immunity, however, raises a new set of questions about the interaction between interjurisdictional immunity and paramountcy. I have discussed some of these questions at length elsewhere. ${ }^{27}$ But, putting the matter straightforwardly, provincial interjurisdictional immunity is inconsistent with any universal application of federal paramountcy. In the case of a federal statute that conflicts with provincial legislation enacted in an area of exclusive provincial power, it would be inappropriate to follow blindly the doctrine of federal paramountcy. If a court did so, the doctrine of provincial interjurisdictional 
immunity that the Court in Canadian Western Bank went out of its way to rescue from judicial oblivion would become meaningless.

If provincial interjurisdictional immunity had been found to be applicable in $P H S$, it would have confirmed and clarified the doctrine. This would have been particularly the case if the government had made explicit the provincial legislative foundations for the operation of the Insite clinic (without which no paramountcy issue arises). The Court is explicit that paramountcy would favour the criminal law over any provincial jurisdiction in the case. ${ }^{28}$ Yet, the Court goes out of its way to say that " $[w]$ hile the Attorney General of Canada did not rely on this principle [of federal paramountcy], it merits mention." 29 Then, the Court goes on to say that "[a] detailed analysis of paramountcy is unnecessary in this case." ${ }^{30}$ It would seem that the Court deliberately attempts to keep alive, albeit on life support, the notion of exclusive federal paramountcy. But to do so is merely to dodge the question that must arise based on the recognition of provincial interjurisdictional immunity and even the readiness to consider an argument for its application in PHS. The division of powers discussion in PHS is laden with logical tensions in so far as the Court goes out of its way to raise an argument that is inconsistent with the provincial interjurisdictional immunity argument that was actually raised in the case.

The Court in PHS, with its attention drawn to section 7, is not especially focused on the interjurisdictional immunity question, because the argument is not needed for the claimants' success in the result. Perhaps because interjurisdictional immunity is not a strong focus, the Court does not explore the interaction of interjurisdictional immunity and paramountcy. The judgment does not follow the rather peculiar majority guidance in Canadian Western Bank concerning the order in which to analyze paramountcy and interjurisdictional immunity issues. $^{31}$ The majority there instructed that a court should commence with paramountcy. ${ }^{32}$ Instead, the Court now discusses interjurisdictional immunity first and then makes a quick side note about paramountcy.

Though PHS could have been the case that clarified provincial interjurisdictional immunity and its implications for paramountcy not always working in favour of the federal government, McLachlin CJC's judgment simply leaves those matters suspended. Indeed, in doing so, the Court misses a route by which it could have avoided the potentially problematic section 7 approach it adopted.

\section{Missed Possibilities for a Federalism-Based Resolution of the Case}

Some might of course argue that the Court had good reason for not applying interjurisdictional immunity in favour of the province in this case. The PHS judgment, which starts by referring to interjurisdictional immunity as having been "confine[d]," ${ }^{33}$ actually does admit that "[w]hile the doctrine of interjurisdictional immunity has been narrowed, it has not been abolished." ${ }^{4}$ Indeed, there is a restatement of its availability for provincial powers. ${ }^{35}$ However, there is a suggestion that caution should be exercised in relation to interjurisdictional immunity, with one statement going beyond caution to say that "before applying the doctrine of interjurisdictional immunity in a new area, courts should ask whether the constitutional issue can be resolved on some other basis." ${ }^{36}$ This seemingly includes even section 7 of the Charter!

The reasons for this caution are not all equally strong. Notably, the "legal vacuums" that keep appearing as a sort of spectre haunting the Court when it considers interjurisdictional immunity are an underdeveloped notion. As described by McLachlin CJC in the specific context, "[e]xcluding the federal criminal law power from a protected provincial core power would mean that Parliament could not legislate on controversial medical procedures, such as human cloning or euthanasia. The provinces might choose not to legislate in such areas, and indeed might not have the power to do so." ${ }^{37}$ Whether a core of provincial health jurisdiction would have to include euthanasia-related issues is a complex question to consider on another occasion. What arises more easily in a consideration of this passage is a blurring of categories 
between areas where provinces "might choose not to legislate" and those where nobody has a power to legislate. If a matter were found to be at a core of a provincial area of jurisdiction, the provinces presumably would have the power to legislate on it. If they "choose not to legislate," all the references to a "legal vacuum" amount to a reference to the possibility of not having everything regulated. Why constitutional jurisprudence should be driven by a worry about governments making a democratic choice to leave some particular matter within the realm of human freedom rather than that of government bureaucracy is, frankly, unclear.

There is a more compelling reason referenced in the Court's judgment for not applying interjurisdictional immunity in this case, namely the uncertainty of the shape of a "core" of provincial health jurisdiction. Were such a core undefinable, that fact would be a very good reason for questioning the use of interjurisdictional immunity. However, on the facts of the case, had the Court sketched out a core of provincial health care jurisdiction, it might have been able to do so in a carefully circumscribed way that would have had fewer consequences than the implications that are sure to flow from their decision using section 7 of the Charter. Indeed, there is an established jurisprudence on a provincial jurisdiction over drug treatment from a health care perspective, ${ }^{38}$ and the Court could simply have developed a core of this more specific provincial drug treatment power for the very specific circumstance in which a province chooses to use an injection site as part of its health care policy.

The difficulty is that in their arguments, the claimants did not render this core more certain. The results of an ongoing uncertainty regarding provincial health jurisdiction affected the possibility for a strong interjurisdictional immunity argument. And that is one of the practical consequences identifiable from the case. In order to seek the benefits of the doctrine, parties must make clear the scope and consequences of the interjurisdictional immunity claim at issue.

The specific circumstance in which a province chooses to use an injection site as part of its health care policy would remain limited even if that decision were within provincial jurisdiction. It would remain circumscribed and site-specific in that the possibility would apply only in the context of injection sites established by provinces that made this decision about particular sites within their provincial democratic processes. In contrast, the section 7 Charter conclusion reached by the Court is not confined in that way but could apply anytime anybody can generate evidence of the merits of a particular site that swayed the courts, regardless of the views of any democratically elected government.

The federalism-based approach would have avoided generating the section 7 precedent that now has the previously discussed judicial activist implications for such contexts as prostitution, euthanasia, and health care. A federalism-based approach would have been easily discernible in the circumstances of the case and truer to the purported aims of the Court in terms of a decision with more limited implications in future legal decision-making.

This argument is of course simply an instantiation of broader points one could make about the possible reasons for courts to adopt federalism-based alternatives to Charter conclusions where they can do so. Charter-based restrictions on governments are of course mandated when genuinely dictated by the Charter, but they are always, to a degree, democracyrestricting. By contrast, federalism-based decisions are always a choice as between different democratically-elected governments and are thus always democracy-supporting. Where a narrow federalism-based ruling can easily be substituted for a Charter-based ruling, there will thus generally be democratically-based reasons for the courts to opt for the federalismbased argument in place of the Charter-based argument.

\section{Notes}

* Professor of Law, University of Saskatchewan. B.A. (Reg.), J.D. (Sask.), B.C.L., M.Phil., D.Phil. (Oxon.). Member of the Ontario and Saskatchewan bars. I thank Sarah Burningham, Mark Carter, Ubaka Ogbogu, and Michael Plaxton for comments on a prior draft of the paper. I also 
thank Patricia Paradis and the University of Alberta Centre for Constitutional Studies for the opportunity to present a prior draft of the paper in the context of the Centre's richly stimulating 2012 Constitutional Law Symposium.

12011 SCC 44, [2011] 3 SCR 134 [PHS cited to SCC].

2 See e.g. Hester Lessard, "Jurisdictional Justice, Democracy and the Story of Insite" (2010) 19 Const Forum Const 93 (arguing for more contextual orientation within federalism analysis); Gillian Calder, "Insite: Right Answer, Wrong Question" (2010) 19 Const Forum Const 113 (arguing for culturally sensitive federalism analysis). I also note Alana Klein's recent conference presentations (such as her "Section 7 of the Charter and the Principled Assignment of Legislative Jurisdiction", presented at the Law and Society Association Meeting in Honolulu in June 2012), in which part of her argument appears to be for a Charter-influenced division of powers analysis. One important exception to this generalization is from Bruce Ryder, who briefly affirms the importance of more formal federalism rules even in contexts like this case: "Equal Autonomy in Canadian Federalism: The Continuing Search for Balance in the Interpretation of the Division of Powers" (2011) 54 Sup Ct L Rev 565 at 594 (noting a "yawning gap between the federal principle and the interjurisdictional immunity doctrine" and calling for doctrinal steps that would reduce tensions between the federal principle and the current shape of the latter doctrine).

For an explanation of interjurisdictional immunity, see Dwight Newman, “Canada's Re-Emerging Division of Powers and the Unrealized Force of Interjurisdictional Immunity" (2011) 20 Const. Forum Const. 1 at note 5. (stating that "ii]nterjurisdictional immunity is the doctrine that one level of government's legislation is inapplicable to the extent that it would intrude on the core of the other level's head of power, particularly in relation to a work, thing, or undertaking under that head of power.") See also the Centre for Constitutional Studies' keyword entry for interjurisdictional immunity at http://www.law.ualberta.ca/ centres/ccs/keywords/?id=71.

See PHS, supra note 1 at para 140 (trying to minimize the reach of the decision and stating that its application even to other safe injection facilities would need to be based upon very specific evidentiary support: "[ $t$ ]he conclusion that the Minister has not exercised his discretion in accordance with the Charter in this case is not a licence for injection drug users to possess drugs wherever and whenever they wish. Nor is it an invitation for anyone who so chooses to open a facility for drug use under the banner of a 'safe injection facility')."

5 Controlled Drugs and Substances Act, SC 1996, c 19.

$6 \quad$ PHS, supra note 1.

$7 \quad$ Ibid at paras $127-128$.

$8 \quad$ Ibid at para 131.

$9 \quad$ Ibid at paras 131-33.

10 The section 7 discussion in the case is dramatic in two ways. First, the approach to section $7 \mathrm{I}$ am analyzing has significant implications. Second, the case also significantly opens up new kinds of arguments in terms of the types of constitutional challenges available, with a lower court recently describing them as follows: "Constitutional challenge to the individual application of a provision of the Charter to a given exercise of discretion is possible where a Charter right is implicated by the decision involved," $R v$ Serdyuk, 2012 ABCA 205 at para 19 (Watson JA, dissenting). See also UFCW, Local $401 v$ Alberta (AG), 2012 ABCA 130 , para 40 (deriving the principle that a particular discretionary decision can be scrutinized for conformity with Charter values). However, I will not even venture into this second dimension.

$11 \quad$ PHS, supra note 1 at para 133.

12 See especially Oregon (Department of Human Resources) v Smith, 494 US 872 (1990) (with, aside from the less accommodative approach of Scalia J toward religion, even the opinion of O'Connor $\mathrm{J}$ upholding an approach oriented to significant religious exemptions from legislated requirements nonetheless allowing for the importance of uniform application of drug laws so as to override that consideration, and containing a number of points in favour of the significance of that uniform application).

13 Carterv Canada (AG), 2012 BCSC 886, passim. (numerous references to the PHS decision as helping to support claims that section 7 analysis had changed significantly since the Court upheld this restriction in Rodriguez v British Columbia (AG), [1993] 3 SCR 519).

14 Canada (AG) v Bedford, 2012 ONCA 186, leave to appeal to SCC granted, 2012 CanLII 64742 (with PHS serving as a foundation for the Court's reasoning on section 7, but with the case to be tested before the Supreme Court of Canada).

15 PHS, supra note 1 at para 93. The Court's paragraph goes on to cite a number of cases on the point: “[...] Morgentaler (1988), at p. 59, per Dickson C.J., and pp. 105-6, per Beetz J.; Rodriguez $v$ British Columbia (Attorney General), [1993] 3 
S.C.R. 519, at p. 589, per Sopinka J.; Chaoulli, at para. 43, per Deschamps J., and, at paras. 118-19, per McLachlin C.J. and Major J.; R. $v$ Parker (2000), 188 D.L.R. (4th) 385 (Ont C.A.)."

16 PHS, supra note 1 at paras 50-51 (stating at para 51 that Quebec "appears to confuse the constitutional validity of a law with the applicability of a valid law").

17 Ibid at para 55 (suggesting that the authorities support such limitation only where the federal statute makes room for the provincial statutes).

$18 \quad$ Ibid at paras 57-70.

19 I offer the same brief-form explanation in Dwight Newman, "Canada's Re-Emerging Division of Powers and the Unrealized Force of Reciprocal Interjurisdictional Immunity" (2011) 20:1 Const Forum Const 1.

20 See e.g. Constitution Act, 1867, s 91 ("the exclusive Legislative Authority of the Parliament of Canada extends to all Matters coming within the Classes of Subjects next hereinafter enumerated..."), section 92 ("In each Province the Legislature may exclusively make Laws in relation to Matters coming within the Classes of Subjects next thereinafter enumerated...”).

$21 \quad$ Ibid at paras 62-63.

22 Ibid at para 64.

23 PHS, supra note 1 at paras 67-69.

24 Canadian Western Bank v Alberta, 2007 SCC 22, [2007] 2 SCR 3 [cited to SCC].

25 Ibid at paras $35,67,77$.

26 PHS, supra note 1 at paras 67-68.

27 See especially Newman, supra note 19, passim.

28 See PHS, supra note 1 at para 72.

29 Ibid at para 71.

$30 \quad$ Ibid at para 72.

31 Canadian Western Bank, supra note 24 at paras 76-78.

32 This instruction has been ignored in other judgments as well, arguably rightfully so. See e.g. Canada $(A G) v$ Canadian Owners and Pilots Association, 2010 SCC 39, [2010] 2 SCR 536.

33 PHS, supra note 1 at para 61.

$34 \quad$ Ibid at para 65.

35 Ibid.

36 Ibid.

37 Ibid at para 69 [emphasis added].

38 This is clear from Schneider $v$ The Queen, [1982] 2 SCR 112, in which the court held that a province could establish community-based treatment for heroin users based on a provincial aspect in what might have otherwise seemed an area covered by the federal criminal law power. 